\title{
Preferences for menu labelling formats of young adults in Brazil and in the United Kingdom
}

\author{
Preferências de adultos jovens por diferentes \\ formatos de informações nutricionais em \\ restaurantes no Brasil e Reino Unido
}

Renata Carvalho de OLIVEIRA ${ }^{1}$

Ana Carolina FERNANDES ${ }^{1}$

Rossana Pacheco da Costa PROENÇA ${ }^{2}$

Heather HARTWELL ${ }^{3}$

Vanessa Mello RODRIGUES ${ }^{1}$

Giovanna Medeiros Rataichesck FIATES ${ }^{1}$

\section{A B S T R A C T}

\section{Objective}

This pilot study was aimed at exploring preferences of young adults in two different contexts on restaurant menu labelling formats.

\section{Methods}

Five focus groups were conducted with 36 participants, two focus groups with 11 participants in Brazil and three focus groups with 25 in the United Kingdom. Themes originating from the content analysis of the transcriptions were organised around four possible menu labelling formats: 1) numerical information on calories; 2) numerical

\footnotetext{
1 Universidade Federal de Santa Catarina, Núcleo de Pesquisa de Nutrição em Produção de Refeições, Programa de Pós-Graduação em Nutrição. Florianópolis, SC, Brasil.

2 Universidade Federal de Santa Catarina, Centro de Ciências da Saúde, Departamento de Nutrição. Campus Universitário, s/n., Trindade, 88040-970, Florianópolis, SC, Brasil. Correspondência para/Correspondence to: RPC PROENÇA. E-mail: <rossana.costa@ufsc.br>.

${ }^{3}$ Bournemouth University, International Centre for Tourism and Hospitality Research, The Foodservice and Applied Nutrition Research Group. Bournemouth, DT, United Kingdom.

Support: Conselho Nacional de Desenvolvimento Científico e Tecnológico (Process no 485004/2012-7) and Coordenação de Aperfeiçoamento de Pessoal de Nível Superior.

Article based on the doctoral dissertation of RC OLIVEIRA, intitled: "Modelos de informação nutricional e escolhas alimentares saudáveis de estudantes universitários”. Universidade Federal de Santa Catarina; 2016.
} 
information on calories and nutrients; 3) traffic light system plus Guideline Daily Amounts; 4) food information with ingredients list plus highlighted symbols.

\section{Results}

In both countries, participants preferred the ingredients list plus symbols format, considered more comprehensive and useful to make an informed food choice. Organic food and vegetarian symbols were the ones considered most important to appear on restaurant menu labels with ingredients list. However, most participants in Brazil and in the United Kingdom rejected the information restricted to calories and calories plus nutrients formats, saying that these would not influence their own choices.

\section{Conclusion}

This is the first multicultural qualitative study exploring preferences of people living in different countries with different eating habits, but where menu labelling is voluntary. Results evidenced similarities in participants' likes and dislikes for menu labelling formats in these two different contexts. Discussions showed participants in both countries prefer qualitative information than numerical information, suggesting that ingredients list and symbols provide information that people want to see on the menu.

Keywords: Feeding behavior. Focus group. Nutritional focts. Qualitative research. Restaurants.

\section{R E S U M O}

\section{Objetivo}

Este estudo piloto teve como objetivo explorar as preferências de adultos jovens em dois diferentes contextos, quanto a formatos de informações nutricionais em restaurantes.

\section{Métodos}

Cinco grupos focais foram conduzidos com 36 participantes, dois grupos focais com 11 participantes no Brasil e três grupos com 25 no Reino Unido. Os temas originados da análise de conteúdo das transcrições foram organizados em quatro possiveis formatos de informação nutricional em restaurante: 1) informação numérica de calorias; 2) informação numérica de calorias e nutrientes; 3) sistema de semáforo nutricional acrescido de valor diário de referência; 4) informação alimentar contendo lista de ingredientes e símbolos de destaque.

\section{Resultados}

Em ambos os países, os participantes preferiram o formato com lista de ingredientes e símbolos, considerando-o mais compreensivel e útil para realizar escolhas alimentares informadas. Os símbolos de alimento orgânico e vegetariano foram considerados mais importantes para serem disponibilizados junto à lista de ingredientes nos restaurantes. Entretanto, a maioria dos participantes no Brasil e no Reino Unido rejeitou o formato contendo apenas a informação de calorias e de calorias mais nutrientes, afirmando que estes formatos poderiam não influenciar suas escolhas alimentares.

\section{Conclusão}

Esse é o primeiro estudo qualitativo multicultural a explorar as preferências de pessoas vivendo em diferentes países, com diferentes hábitos alimentares, mas onde a informação nutricional em restaurantes é voluntária. Os resultados evidenciaram similaridades nas preferências e rejeições quanto aos diferentes formatos de informação nutricional em restaurante, nesses dois diferentes contextos. O estudo mostrou que os participantes em ambos os países preferiram a informação qualitativa em detrimento à informação numérica, sugerindo que o formato contendo lista de ingredientes e símbolos fornece a informação que as pessoas querem ver nos cardápios em restaurantes.

Palavras-chave: Comportamento alimentar. Grupos focais. Informação nutricional. Pesquisa qualitativa. Restaurante.

\section{NTRODUCTION}

Studies have reported that the high energy density and fat contents of foods eaten out of home may be associated with weight gain and obesity [1,2]. Thus, menu labelling is a public health strategy designed to educate consumers and prevent obesity and other chronic diseases, 
due to the potential to influence food choices, and guide consumer healthy selection $[3,4]$.

The provision of menu labelling has been widely debated around the world. However, only in the United States of America is it mandatory under federal law; there, restaurants and similar food service establishments that are part of a chain of 20 or more must provide calorie information on their menus [5].

In Brazil, the provision of menu labelling is voluntary. Although there is no national legislation, the subject information is being discussed by Agência Nacional de Vigilância Sanitária (Brazilian Health Surveillance Agency) and Brazilian government recommends the provision of menu labelling, but without suggesting formats to be adopted [6].

In the United Kingdom, the provision of menu labelling is also voluntary [7], however the discussion has been occurring for a long time and some formats, as traffic light system has been tested on menus $[8,9]$.

There is no one recommended design to provide menu labelling in restaurants, and the way this information is made available varies substantially. Because of the lack of standardisation and definition on what is the best menu labelling design a variety of nutritional information formats for packaged food are being adapted for restaurant use [10].

Studies have shown that calories, calories and nutrients, calories plus other factors such as traffic light system are the most tested information in restaurants [11-14]. These studies showed contradictory results and there is no consensus of which menu labelling format is the most effective to help consumers make an informed and healthy choice, as well as what format would be preferred by consumers to be available in restaurants.

Furthermore, research aimed at understanding the consumer's preferences from different countries for different menu labelling formats is scarce. This approach suggests the originality and relevance of the present research, since studies testing menu labelling format usually oversee this kind of preliminary analysis.

According to Gatley et al. [15], from a cross-cultural qualitative research, it would be possible to observe deeply similarities and differences across socio-cultural settings for better understanding of the complexities of such phenomena.

Thus, the goal of this qualitative research was to explore university young adults' preferences for menu labelling formats in different contexts, in Brazil and in the United Kingdom. Despite the numerous differences between the both countries, the United Kingdom was chosen to be included in this study because of its prominence in menu labelling academic discussions.

\section{METHODS}

Focus groups were used in this study to gather insight into the preferences of young adults regarding different menu labelling formats.

In both countries, participants were recruited in universities through email messages. To be eligible to participate, volunteers should be at least 20 years old; they should be Portuguesespeaking (in Brazil) or English-speaking (in the United Kingdom) and are not enrolled on a food-related or nutrition degree programs.

Recruitment was discontinued once the same themes continued to emerge across groups and when participants no longer contributed new themes to the overall discussion.

Focus group sessions lasted between 40 and 60 minutes, and comprised five to eleven individuals from both sexes. Before each session, all participants provided informed consent. Research Protocol was approved by Ethics Committee in both countries by Universidade Federal de Santa Catarina and Bournemouth University. Before each session, participants also completed a characterisation questionnaire 
about dietary restrictions and eating out behaviour. The aim was to verify if there was a difference in formats preferences by those who mentioned having food restrictions or having a habit of eating out.

Two focus groups were conducted in a Brazilian university in October 2013, and three focus groups were conducted in a United Kingdom university in March 2014. Although the data collection was carried out a few years ago, the discussion about menu labelling in both countries did not undergo relevant changes that could compromise the interpretation of the results found.

Sessions were conducted by two investigators with one of them acting as moderator and the other observing and taking notes. The same moderator conducted the focus groups in both countries. At the beginning of each session, the moderator outlined the aim of the study to the participants, explained how the activity would be conducted and how confidentiality would be warranted. A semistructured guide was used by the moderator to help guide the discussion and ensure consistency (Chart 1).

After an icebreaker talk, a printed menu contained only numerical information of calories was given to the participants (Figure 1). After this, three other printed menus, similar to the format used in restaurants, with different menu labelling formats were distributed one at a time, followed by a discussion about how those different formats could help participants order dishes and make food choices.

The second menu presented for discussion contained numerical information on calories and nutrients. Since table formats in packaged foods differ between countries, they were adapted to accordance with the rules for packaged foods in Brazil [16] and the European Union [17] (Chart 2).

The third menu presented traffic light system plus Guideline Daily Amounts (GDA) (Figure 2). Studies have been testing this information in different countries, including the United Kingdom; hence this menu labelling format was chosen to be part of the research.

The last contained food information with ingredients list and highlighted symbols (contains gluten, lactose, trans fat, Genetically Modified Organisms (GMO), or is suitable for vegetarian, is organic or locally sourced). This menu labelling format was adapted from a previous study conducted by Feldman et al. [10] (Figure 3).

At the end of each session, the moderator reiterated the conclusions of the focus group by summarizing the groups' answers using the following rhetorical question: "In sum, what menu labelling would you prefer on the menu?".

The sessions were audio-recorded for accuracy of transcription and analysis. The

Chart 1. Semi-structured guide used to conduct the focus groups about menu labelling formats.

\footnotetext{
Question 1 - If you arrive at a restaurant and you see this menu, what would you choose? Why? This type of menu helps you to make appropriate food choices?

Question 2 - And this other menu with calorie information, what do you think about this information? Why? Would this information help you to make appropriate food choices at restaurants? Why?

Question 3 - Another menu with calorie and nutrients information, what do you think about this information? Why? Would this information help you to make appropriate food choices at restaurants? Why?

Question 4 - Another menu with traffic light system plus Guideline Daily Amounts (GDA), what do you think about this information? Why? Would this information help you to make appropriate food choices at restaurants? Why?

Question 5 - The last menu, food information with ingredients list and highlighted symbols, what do you think about this information? Why? Would this information help you to make appropriate food choices at restaurants? Why?

Question 6 - If you have to choose, which menu labelling format you prefer? Why? Do you have some suggest for improvement?
} 


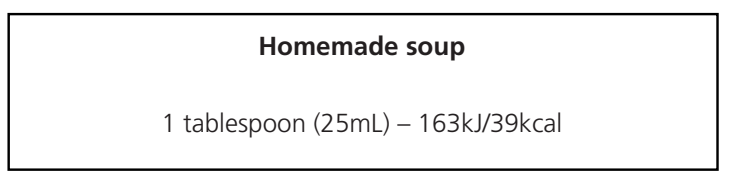

Figure 1. Numerical information on calories format used in focus groups.

Homemade soup

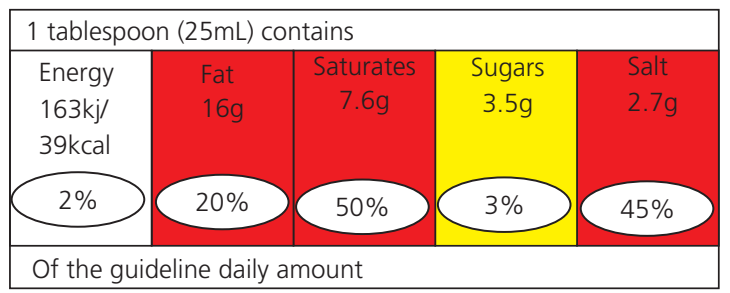

Figure 2. Traffic light system plus Guideline Daily Amounts format used in focus groups.

\section{Homemade soup $\mathrm{T}$}

Ingredients: potato, bacon, onion, cream, butter, wheat flour, garlic, salt, black pepper.

\section{$\mathrm{T}_{\mathrm{GM} \text { (Genetically Modified Food) }} \downarrow$ contains lactose $_{\text {}}$ \\ G contains gluten}

Figure 3. Ingredients list plus highlighted symbols format used in focus groups.

recordings were fully transcribed verbatim and those conducted in Portuguese were translated to English. Content analysis was used to analyse the transcripts considering similarities and differences [18].

\section{RE S U L T S}

\section{Overall characteristics of participants}

Thirty-six young adults participated in the focus groups, eleven participants in Brazil and twenty-five in the United Kingdom. This difference in the number of participants in the countries was due to the greater acceptance in participating in the survey by the British. Furthermore, focus group sessions were disrupted when data was saturated due to saturation of ideas or themes in each group occurring after the second session in Brazil and the third session in the United Kingdom.

More than half of them were female and ages ranged from 20 to 30 years. Almost all participants mentioned the habit of eating out, $48 \%$ of them mentioned having dietary restrictions (36\% in Brazil and 12\% in the United Kingdom). From those with dietary restrictions, all participants reported restrictions of foods with animal origin in Brazil and 33\% in the United Kingdom. Moreover, in the United Kingdom, 67\% of the people that reported dietary restrictions had the condition diabetes.

Themes originated from the analysis of data were organised according to the four menu labelling formats evaluated: (1) Numerical information on calories; (2) Numerical information on calories and nutrients; (3) Traffic light system plus GDA; (4) Ingredients list and highlighted symbols.

\section{Numerical information on calories}

Brazilian participants said that since most of the people do not know what calories are and how to use this information, it would be better to detail ingredients, and not calories. Some Brazilian participants considered calorie information more important on packaged foods, while others said calories did not influence their food choices, as exemplified by a woman statement: "I do not choose food by the amount of calories, but by what I want to eat".

In the United Kingdom, most participants reported this information would not help people make an appropriate food choice. "If I want to eat something, I ignore calories" said one 
female respondent. However, some participants stated calorie information can help people make a healthy choice and choose lower calorie dishes. One woman stated: "It can help, if you know how many calories you need and also the nutritional value of dishes". The menu labelling format containing numerical information on calories was rejected for most participants in Brazil, and was considered useful only by one group of United Kingdom participants.

\section{Numerical information on calories and nutrients}

In both countries, this format was criticized. Most Brazilians respondents mentioned that nutritional information is hard to understand for being very confusing and does not draw attention to the dishes as aggravated by information overload.

Several Brazilians stated that not everyone could understand this information and it would be more interesting to put only the most relevant information on the menu. One man's statement reflected the view of others: "It should highlight the most important nutrient, a warning or a highlight instead of putting the whole table".
In the United Kingdom, most participants said more time would be required to read and understand the information, because many terms are not understood. "There is too much information. This is not a menu, it is nutritional guidance" said one male respondent. One woman stated: "I go to the restaurant to relax; I do not want to have to read". Some participants reported that nutritional tables are good as comparative parameters, but not for menus. One woman said: "You do not have time to read this type of information... Perhaps it could be on the website, because it may be interesting to some people". Another woman said: "It is nice to have the option of having access to this information, but not on the menu".

Regarding the influence on food choices, in both countries, all respondents said this information would not influence their food choices. In the United Kingdom, most participants reported that lots of information, as in this menu labelling format, disrupts the pleasure of food choices. One man added: "When you go to a restaurant you go to have fun and you eat what you want to eat".

Accordingly, in both countries, this menu labelling format was rejected by participants.

Chart 2. Numerical information on calories and nutrients format used in focus groups in Brazil and in the United Kingdom.

\begin{tabular}{|c|c|c|c|c|c|c|}
\hline \multicolumn{3}{|c|}{ White rice 1 tablespoon $(25 \mathrm{~g})$ contains } & \multicolumn{4}{|c|}{ Homemade soup } \\
\hline \multicolumn{2}{|l|}{ Per serving } & \multirow{2}{*}{$\frac{\% \mathrm{DV}}{2}$} & \multicolumn{4}{|c|}{ Nutrition information } \\
\hline Energy & $32 \mathrm{kcal}=134 \mathrm{~kJ}$ & & Typical values & Per $100 \mathrm{~g}$ & Per serving & $\% G D A$ \\
\hline Carbohydrates & $7.0 \mathrm{~g}$ & 2 & Energy & $652.0 \mathrm{~kJ} / 156.0 \mathrm{kcal}$ & $163.0 \mathrm{~kJ} / 39.0 \mathrm{kcal}$ & 2 \\
\hline Proteins & $0.6 \mathrm{~g}$ & 0.8 & Protein & $63.6 \mathrm{~g}$ & $15.9 \mathrm{~g}$ & 11 \\
\hline \multirow[t]{2}{*}{ Total fat } & $11.0 \mathrm{~g}$ & 20 & Carbohy-drate & $156.0 \mathrm{~g}$ & $39.0 \mathrm{~g}$ & 13 \\
\hline & & & Of which sugars & $14.0 \mathrm{~g}$ & $3.5 \mathrm{~g}$ & 3 \\
\hline \multirow[t]{2}{*}{ Saturates fat } & $0 \mathrm{~g}$ & 0 & Fat & $64.0 \mathrm{~g}$ & $16.0 \mathrm{~g}$ & 20 \\
\hline & & & Of which saturates & $30.4 \mathrm{~g}$ & $7.6 \mathrm{~g}$ & 50 \\
\hline Trans fat & $0 \mathrm{~g}$ & - & Fibre & $11.6 \mathrm{~g}$ & $2.9 \mathrm{~g}$ & 11 \\
\hline Fibre & $0.4 \mathrm{~g}$ & 2 & Sodium & $3.6 \mathrm{~g}$ & $0.9 \mathrm{~g}$ & 36 \\
\hline Sodium & $221.0 \mathrm{mg}$ & 9 & Salt equivalent & $10.8 \mathrm{~g}$ & $2.7 \mathrm{~g}$ & 45 \\
\hline
\end{tabular}

Note: Daily Values are based on a diet of $2000 \mathrm{kcal}$ or $8400 \mathrm{~kJ}$.

GDA: Of an adult's Guideline Daily Amount. 


\section{Traffic light system plus GDA}

Most Brazilian participants considered this menu labelling format easy to understand because of the traffic light colours. One woman stated: "The colour scheme draws attention and is easy to read". Only one woman disagreed: "This information is confusing. I do not like it".

Not with standing, most respondents said traffic light system could help them make a healthy choice. One woman said: "We can compare the foods to make a healthy choice".

Two Brazilian participants reported this information could help other people make a healthy choice, but it is not suitable for all types of restaurants. One woman said "I would not like this information in pizzerias or pubs, for example, it would be negative for these restaurants".

In contrast, in the United Kingdom, some participants reported this format is confusing. "I do not understand what the traffic light system is and other people also do not understand" said a female participant. One man stated: "This information is confusing, how can the fried chicken be better than the homemade soup? It is difficult to compare". Another man agreed: "You do not know how anything is prepared through this information, I do not know, it is confusing". Some participants considered this information better for packaged foods. "I think this information is interesting only for packaged food. I would not like to have this information in restaurants" said one woman. Another woman stated: "It is more useful on packaged foods, because we have more time to see and read the information".

Most British participants indicated this format could not help them make an appropriate food choice. For example, one man stated: "For me, it would not change my choice, it makes no difference if it is present or not". Another man agreed: "It does not change my choice if I do not know the ingredients".
Even so many participants considered that this menu labelling format was not ideal for restaurants; this format was the second preferred option for all groups in Brazil and two groups in the United Kingdom.

\section{Ingredients list and highlighted symbols}

In both countries, most participants considered this format easy to understand. They reported it to be the best menu labelling for restaurants. For example, a Brazilian man stated: "This is the best, showing ingredients". Another Brazilian man agreed: "I liked this layout. It is better for people". In the United Kingdom, a female participant said: "It is the most important, especially the description of the ingredients".

Although most participants reported this one is the best format, in both countries participants made suggestions for improvement. In Brazil, for example, one man suggested: "It is the most important menu labelling... it shows all the ingredients including the hidden ingredients. For example, what are the ingredients of mayonnaise?" One woman agreed: "I want to see the complete list of ingredients, but I think that restaurants would put only the most basic ingredients on the menu". Furthermore, participants suggested leaving only the symbols of trans fat, GMO, organic and vegetarian. For them, the specific information about allergens would already be in the ingredients list. "Information on allergens you see on the list of ingredients. The most important information is trans fat" said one woman.

In the United Kingdom, most participants suggested that only the main ingredients needed to be shown on the menu, not the entire list of ingredients. "I think it is unnecessary to know all the ingredients, I do not need to know if it has vegetable oil, salt and pepper, for example", said one male participant. One female participant's opinion: "I do not care if they used olive oil or other oil". "I do not want to see on the list of 
ingredients the word fat, I do not want to know if it is there or not" said another woman.

Although they were of the same opinion as Brazilians on the organic and vegetarian information, as well as, the allergen information already being in the ingredients list, British participants considered some symbols were irrelevant. "The allergens you can see in the ingredients list" said two women. One male participant stated: "I do not have a problem with trans fat and GMO, so this information is not necessary". One woman said: "People do not want to see negative things like trans fat and GMO. We do not want to know".

Regarding the influence on food choices, in both countries, most participants agreed this menu labelling format could help them make appropriate food choices. In Brazil, for example, one woman stated: "This information would absolutely influence my choice of foods". In the United Kingdom, one man said: "This information can make people change their idea of what they will eat".

This menu labelling format was the preferred option by all groups in Brazil and in the United Kingdom. However, participants in both countries said it could be improved.

\section{DISCUSSION}

Results revealed that menu labelling format presenting ingredients list and highlighted symbols was the one chosen by participants in both countries, because according to them it was the easiest one to understand and was the best option to help them make an informed choice.

Results are in agreement with those obtained by other researchers in the United States, who reported that consumers prefer simple menu labelling formats (such as symbols) and are more likely to use menu labelling when the information is easy to understand and requires minimal effort $[19,20]$.
All participants from both countries indicated that they wanted to know the dishes' ingredients and that the presence of ingredients list is important to make food choices. British surveys have shown that people want to know what ingredients are present in the food they eat, and would take into consideration the ingredients information on menus $[21,22]$. However these studies did not reveal why consumers want this information and what ingredients consumers wanted to see on the menu, as was shown in our study.

Regarding the symbols, in both countries, organic food and vegetarian symbols were the ones considered most important to appear on menus. Furthermore, participants considered allergen signaling unnecessary, since allergen ingredients would be mentioned in the ingredients list. Although respondents in the United Kingdom did not care about allergens, allergy information on menus is mandatory since December 2014 across the European Union [17].

While Brazilians considered GMO and trans fat symbols important, United Kingdom participants did not show the same concern about this information. Brazilians could have been more interested in GMO and trans fat information because of their largest exposure to foods containing these components. In both countries, GMO labelling is mandatory on packaged foods $[16,23,24]$. However, in the United Kingdom, there is no commercial production of GM foods and the use of GM ingredients in animal feed and processed food has been rejected by large corporations [25].

In addition, trans fat labelling in packaged foods are mandatory in Brazil $[17,24]$; and the presence of such fat in processed foods has been increasing [26]. Trans fat labelling is not mandatory in United Kingdom, but Roe et al. [27] have shown a considerable decrease in the utilisation of trans fat by the British food industry.

Most participants in both countries rejected the idea of numerical formats (only 
calories and calories plus nutrients table), considering that these information would not influence their food choice. The availability of numerical information can actually be an obstacle to the use of menu labelling, since many people considered it confusing. In a focus group study in the United Kingdom, participants found much information can be confusing, and considered calorie counting an anti-social behavior [28]. Ellison et al. [29], in United States, also identified that numerical labels did not influence food choices.

Furthermore, participants in both countries mentioned that people in general did not know the meaning of calories and therefore this menu labelling format could not influence food choices. According to Blumenthal \& Volpp [30]; Lee et al. [31], despite calorie content being a simple format, consumers may find it difficult to understand and not be familiar with the ideal amount of calories they should consume daily.

Moreover, studies have shown only calorie information is not sufficient to modify consumer behaviour in restaurants, suggesting the inclusion of interpretative or descriptive menu labelling formats, besides calories, need to be present to influence food choices $[11,13,32,33]$.

The traffic light system plus GDA was considered the second best menu labelling option from most participants in both countries. Brazilians considered this information could be easy to understand and could help them make an appropriate food choice. Previous studies conducted in the United Kingdom showed the traffic light system can be effective to encourage healthy choices and can be a good menu labelling format for restaurants [8,9]. Even many British participants considered format as the second preferred menu labelling option, for some students this information is confusing, suitable only for packaged foods and unable to help them with food choices. One possible explanation for the rejection of the traffic light format by some respondents in the United Kingdom is that although they have been exposed to this type of information on packaged foods since 2004, they still think this format is confusing and maybe this type of information is not so clear for consumers [34]. According to Hammond et al. [35], the traffic light system may be better understood on packaged foods because it is possible to read one label at a time and compare packages, which is difficult in a restaurant setting.

This investigation adds to the small number of recent studies regarding food information strategies on restaurant menus. An experimental study with 329 adults in France found that a food information format was perceived as friendlier and drew more attention than nutrients information. However, the authors did not identify which format was preferred by the participants [36]. A survey conducted in Brazil with 300 adults, showed that about $73 \%$ of the respondents considered that food information as provided was very good [37]. However, this was a single study that was conducted in one day only, testing only one menu labelling format and the study did not ask whether the participants had questions or preferences related to the information provided. Additionally, in a focus group study conducted with university students in the USA, among other information, participants selected ingredients list and nutrients/food ingredients icons to be available on the university foodservice menu [10].

Although the results of this study are not generalizable because it is a qualitative research, the results of the focus groups conducted with young adults can be used for comparison with studies with similar population worldwide and as a preliminary step in conducting interventions.

\section{CONCLUSION}

These results from two countries of different continents bring a look across national 
borders on the preference of young adults regarding menu labelling formats.

Although this innovative study was conducted in different contexts, in the both countries were found the agreement among participants in relation to the preference of ingredients list plus symbols format. Also there was agreement in the rejection to numerical information formats. The participants considered it more useful to put only the most relevant information on the menu than a lot of information that can be confusing.

Furthermore, ingredients list and symbols can strengthen the consumer's analysis and decision-making ability, helping to choose healthier foods whilst also allowing the freedom to eat away from home.

Ingredients list plus symbols, by being able to influence positively food choices, could become part of public policy designed as an effective strategy as a strategy to empower consumers, promote health, prevent disease, and address the escalation of obesity and other chronic diseases. The availability of this menu labelling format in restaurants can help ensure consumers' right to information by making informed food choices, especially to people who, for different reasons, have food restrictions. Moreover, it can be used as a format to be adopted in future legislation on menu labelling in Brazil and around the world.

\section{CONTRIBUTORS}

RC OLIVEIRA was responsible for planning the research, for collecting, analyzing and interpreting the data, and for drafting the manuscript. AC FERNANDES contributed to collection, analysis and interpretation of data, as well as drafting and revising the manuscript. RPC PROENÇA was responsible for study design, research orientation and coordination, and revision of the final version of the manuscript. H HARTWELL, VM RODRIGUES and GMR FIATES contributed to the interpretation and discussion of the results and revision of the final manuscript.

\section{REFERE N CES}

1. Bezerra IN, Sichieri R. Eating out of home and obesity: A Brazilian nationwide survey. Public Health Nutr. 2009;12(11):2037-43. https://doi. org/10.1017/S1368980009005710

2. Naska A, Orfanos P, Trichopoulou A, May AM, Overvad K, Jakobsen UM, et al. Eating out, weight and weight gain. A cross-sectional and prospective analysis in the context of the EPICPANACEA study. Int J Obes. 2011;35(3):416-26.

3. Bleich SN, Pollack KM. The publics' understanding of daily caloric recommendations and their perceptions of calorie posting in chain restaurants. BMC Public Health. 2010;10:121. https://doi.org/ 10.1186/1471-2458-10-121

4. Malik VS, Willet WC, Hu FB. Global obesity: Trends, risk factors and policy implications. Nat Rev Endocrinol. 2013;9(1):13-27. https://doi.org/10. 1038/nrendo.2012.199

5. United States of America. Patient protection and affordable car act. Section 4205: Nutrition labeling of standard menu items at chain restaurants. 2014 [cited 2015 Sept 11]. Available from: http:// docs.house.gov

6. Ministério da Saúde (Brasil). PNAN: Política Nacional de Alimentação e Nutrição. Braślia: Editora do Brasil; 2013.

7. Department of Health (United Kingdom). Public health responsibility deal: Sign up and pledge to improve public health in England. London: Departament of Health; 2012 [cited 2015 Oct 1]. Available from: http://responsibilitydeal.dh.gov.uk

8. Heathcote F, Baic S. The effectiveness and acceptability of a traffic light labelled menu with energy information to signpost customers towards healthier alternatives in a table service restaurant. J Human Nutr Diet. 2011;24(4):375-407. https:// doi.org/10.1111/j.1365-277X.2011.01177_21.x

9. Gerlach L. The effect of displaying traffic-light nutritional labels in a university cafeteria on students' food choice. Plymouth Stud J Health Soc Work. 2013;5:13-29.

10. Feldman C, Hartwell H, Brusca J. Using student opinion and design inputs to develop an informed university foodservice menu. Appetite. 2013;69:80-8. https://doi.org/10.1016/j.appet.2013.05.009

11. Kiszko KM, Martinez OD, Abrams C, Elbel B. The influence of calorie labeling on food orders and consumption: A review of the literature. J Commun Health. 2014;39(6):1248-69. https://doi. org/10.1007/s10900-014-9876-0

12. Long MW, Tobias DK, Cradock AL, Batchelder H, Gortmaker SL. Systematic review and meta-analysis 
of the impact of restaurant menu calorie labeling. Am J Public Health. 2015;105(5):e11-e24. https:// doi.org/10.2105/AJPH.2015.302570

13. Sinclair S, Cooper M, Mansfield ED. The influence of menu labeling on calories selected or consumed: A systematic review and meta-analysis. J Acad Nutr Diet. 2014;114(9):1375-88. https://doi.org/ 10.1016/j.jand.2014.05.014

14. Swartz JJ, Braxton D, Viera A J. Calorie menu labeling on quick-service restaurant menus: An updated systematic review of the literature. Int J Behav Nutr Phys Activ. 2011;8:135. Available from: https://doi.org/10.1186/1479-5868-8-135

15. Gatley A, Caraher M, Lang T. A qualitative cross cultural examination of attitudes and behaviour in relation to cooking habits in France and Britain. Appetite. 2014;75(1):71-81. https://doi. org/10.1016/j.appet.2013.12.014

16. Agência Nacional de Vigilância Sanitária. Resolução RDC n 360, de 23 de dezembro de 2003. Aprova regulamento técnico sobre rotulagem nutricional de alimentos embalados, tornando obrigatória a rotulagem nutricional. Diário Oficial [da] República Federativa do Brasil. 2003.

17. European Communities. Regulation (EU) $n^{\circ}$ $1169 / 2011$ of the European Parliament and of the Council of 25 October 2011 on the provision of food information to consumers, amending Regulations (EC) $n^{\circ} 1924 / 2006$ and (EC) $n^{\circ} 1925 / 2006$ of the European Parliament and of the Council, and repealing Commission Directive 87/250/EEC, Council Directive 90/496/EEC, Commission Directive 1999/10/EC, Directive 2000/13/EC of the European Parliament and of the Council, Commission Directives 2002/67/EC and 2008/5/EC and Commission Regulation (EC) n 608/2004. Official J Eur Union. 2011;304(62):18-63.

18. Bardin L. Análise de conteúdo. $4^{a}$ ed. Lisboa: Edições (70); 2010.

19. Lando AM, Labiner-Wolfe J. Helping consumers make more healthful food choices. Consumer views on modifying food labels and providing point-of purchase nutrition information at quick-service restaurants. J Nutr Educ Behav. 2007;39(3):157-63. https://doi.org/10.1016/j.jneb. 2006.12.010

20. Morley B, Scully M, Martin J, Niven P, Dixon H, Wakefield M. What types of nutrition menu labelling lead consumers to select less energydense fast food? An experimental study. Appetite. 2013;67(1):8-15. https://doi.org/10.1016/j. appet.2013. 03.003

21. Food Standards Agency (United Kingdom). Consumers give their views on eating out. London: Food Standards Agency; 2008 [cited 2015 Dec 11].
Available from: http://www.food.gov.uk/news/ newsarchive/2008/jun/eatout

22. Mackison D, Wrieden W, Anderson A. Making an informed choice in the catering environment: What do consumers want to know? J Hum Nutr Diet. 2009; 22(6):567-73. https://doi.org/10.1111/j. 1365-277X.2009.01000.x

23. Presidência da República (Brasil). Lei $n^{\circ} 11.105$, de 24 de março de 2005: estabelece normas de segurança e mecanismos de fiscalização de atividades que envolvam organismos geneticamente modificados - OGM e seus derivados. Diário Oficial [da] República Fe-derativa do Brasil. 2005.

24. European Communities. Regulation (EC) $n^{\circ}$ $1830 / 2003$ of the European Parliament and of the Council of 22 September 2003 concerning the traceability and labelling of genetically modified organisms and the traceability of food and feed products produced from genetically modified organisms and amending Directive 2001/18/EC. Official J. 2003;268:24-8.

25. Department for Environment, Food and Rural Affairs (United Kingdom). Making the food and farming industry more competitive while protecting the Environment. London: Department for Environment, Food and Rural Affairs; 2014 [cited 2015 Sept 11]. Available from: https://www. gov.uk/government/policies/making-the-foodand-farming-industry-morecompetitive-whileprotecting-the-environment/supporting-pages/ genetic-modification

26. Silveira BM, Gonzalez-Chica DA, Proença RPC. Reporting of trans-fat on labels of Brazilian food products. Public Health Nutr. 2013;16(12):2146-53. https://doi.org/10.1017/\$1368980013000050

27. Roe $M$, Pinchen $H$, Church $S$, Elahi $S$, Walker $\mathrm{M}$, Farron-Wilson $\mathrm{M}$, et al. Trans fatty acids in a range of UK processed foods. Food Chem. 2013;140(3):427-31. https://doi.org/10.1016/J.foodchem. 2012.08.067

28. Alexander M, O'Gorman K, Wood K Nutritional labelling in restaurants: Whose responsibility is it anyway? Int J Contemp Hosp Mana. 2010;22(4):572-9. https://doi.org/10.1108/09596111011042758

29. Ellison B, Lusk JL, Davis D. The effect of calorie labels on caloric intake and restaurant revenue: Evidence from two full-service restaurants. J Agric Appl Econ. 2014;46(2):173-91.

30. Blumenthal K, Volpp KG. Enhancing the effectiveness of food labeling in restaurants. J Am Med Assoc. 2010;303(6):553-4. https://doi.org/10.1001/jama. 2010.85

31. Lee JWC, Shimizu M, Wansink B. You taste what you see: Do organic labels bias taste perceptions? 
Food Qual Prefer. 2013;29(1):33-9. https://doi. org/10.1016/j.foodqual.2013.01.010

32. Fernandes AC, Oliveira RC, Rodrigues VM, Fiates GM, da Costa Proença RP. Perceptions of university students regarding calories, food healthiness, and the importance of calorie information in menu labeling. Appetite. 2015;91:173-8. https://doi.org/10. 1016/J.appet.2015.04.042

33. Schornack B, Rozensher S. The effects of menu calorie labeling on consumer food choice behavior. Am J Health Sci. 2014;5(1):29-36. https://doi.org/10. 19030/ajhs.v5i1.8615

34. Food Standards Agency (United Kingdom). Frontof-pack traffic light signpost labelling: Technical guidance. London: FSA; 2007.

35. Hammond D, Goodman S, Hanning R, Daniel S. A randomized trial of calorie labeling on menus.
Prev Med. 2013;57(6):860-6. https://doi.org/10.10 16/j.ypmed.2013.09.020

36. Gomez P, Minous AE. L'influence du format de l'l'étiquetage sur l'utilisation et la compréhension de l'information nutritionnelle: résultats d'une expérimentation menée en restauration collective. Rev Epid Sante Publ. 2012;60(1):9-18.

37. Barbieri T, Rodrigues KS, Silva SF, Medeiros LB, Saccol ALF. Consumer attitudes toward information displayed at food buffets in commercial restaurants. Ciênc Tec Alim. 2012;32(4):798-803.

Received: June 13, 2016

Final version: November 24, 2016 Approved: December 15, 2016 